\title{
THE RENTIER STATE, AUTHORITARIAN REGIME AND MASS MEDIA: INDONESIA UNDER SUHARTO DURING THE OIL BOOM PERIOD
}

\author{
Tenny Widya Kristiana ${ }^{a}$
}

\begin{abstract}
Scholars develop two different thoughts of natural resource wealth and its relations to political stability, namely - the resource curse and the rentier state. In the rentier state discourse, the revenue from resource extraction is used to buy off peace through several methods, such as patronage, repression, external support and large-scale distributive policy. The rentier economy concept becomes an important subject to explain oil economies in oil-rich countries across the world, especially in the Middle East region. This paper explores the rentier practice outside the Middle East by focusing on Southeast Asia. It uses a single case study - Indonesia under Suharto during the oil boom period. Two main questions are addressed by this paper - what kind of rentier state practice can be found from the authoritarian government especially during the oil boom period, and how the local/regional newspapers report on and react to the government rentier state practices? The paper relies on nine local, and three national newspapers as its primary data, supported by secondary sources to answer those questions. The finding shows that the national and local newspapers wrote different reports on rentier practices and all newspapers adopted three different positions on rentier practices - pro-government, critical to government, and neutral position.
\end{abstract}

Keywords: rentier state, Indonesia, newspapers, oil boom

\section{INTRODUCTION}

Political science scholars develop two different theories on natural resource wealth and its relations to political stability, namely the theory of resource curse, and the theory of rentier state. The resource curse theory argues that a state, which has abundant natural resources, tends to be less democratic and politically unstable. The rentier state theory provides an opposite argument by arguing that the natural resource wealth can be used by the state to consolidate political control and stability. Rentier state put the state as the main actor of rent distribution with its main goal being to buy off peace. There are at least four methods to buy off peace, namely patronage, external support, repression, and large-scale distributive policy. The four method practices lead to political stability.

Study on rentier state shows several findings. The rent distribution leads to the survival of authoritarian regimes for long-term periods. Based on the Global State Revenues and Expenditures dataset within 161 political regimes between 1946-2006, the result shows there is a relation between hydrocarbons rent with authoritarian regime survival (Lucas \& Richter, 2016). Governments that practice rentier-based

\footnotetext{
a Tenny Widya Kristina (tenny@suou.waseda.jp) is a member of Pacific Forum's Young Leaders Program, Hawaii, United States of America.
} 
economies tend to impose low taxes on citizens. The government income relies more on the oil revenue, which makes them stand independently from its citizens. The low tax that citizens pay turns them to be less demanding on government accountability. In oil wealthy countries, oil revenue is part of national income and it brings the focus of academia on state level activities, and state as the main actor of rentier state practice since state is the rent distributor. There is limited study on the rentier state practice from the perspective of rent receiver, the citizens.

\section{LITERATURE REVIEW ON INDONESIA AS A RENTIER STATE}

Discourse on Indonesia as a rentier state is different from other oil rich countries in the Middle East, Africa or South America. Indonesia keeps producing crude oil from before it joined OPEC to the present, but oil production continues to decline and export revenue from oil is falling. Indonesia's oil era was during the oil boom period - during the time of Oil Shocks I and II. As the boom period had passed, the rentier state theory is applicable to the limited time. During the period, Indonesia was also under Suharto's authoritarian government, thus, the rentier state theory becomes viable for Indonesia as a case study.

Researches on oil boom period and Indonesia under Suharto's authoritarian regime are widely found, but research that specifically uses rentier state theory approach can be found as early as 1990. Richard Tanter (1990) wrote an article "Oil, IGGI and US Hegemony: The Global Preconditions for Indonesia Rentier Militarization" for an edited book published by Monash University. A dissertation by Karissa Price (1998) from Harvard University used resource curse theory approach to explain the institution and management during the oil boom period in Indonesia and Venezuela. Andrew Rosser (2007) added a resource curse study on Indonesia with his work "Escaping the Resource Curse: The Case of Indonesia", published in the Journal of Contemporary Asia.

Benjamin Smith became one of the scholars who used rentier state approach for his paper as well as his book to explain oil politics and authoritarian regimes in Iran and Indonesia. Smith's (2006) article, "The wrong kind of crisis: Why oil booms and busts rarely lead to authoritarian breakdown" explains the different findings about regime survival in Iran and Indonesia. A year later, he published a book with the title Hard Time in the Lands of Plenty: Oil Politics in Iran and Indonesia, focusing on when a country becomes oil rich and its relations with late development by using rentier state approach. A recent work related to rentier state theory was written by Marcus Mietzner (2018). His article, "Authoritarian elections, state capacity, and performance legitimacy: Phases of regime consolidation and decline in Suharto's Indonesia", focuses on authoritarian regime, and uses rentier state theory as one of his approaches to support his argument that regime survival relies very much on state capacity.

\section{METHODOLOGY}

The research methodology starts with the research design, with two research questions to be addressed. First, what kind of rentier state practice did the Suharto's government adopt during the oil boom period? Second, how did the local/regional newspapers report on and react to the government rentier state practices? The research is 
qualitative in nature with Indonesia as the case study. The research aims of this study indicate that the case study method will most likely become an exploratory case study. A single case study with a limited time scope is chosen with the goal of getting a better understanding of the rentier state practices and newspapers opinions towards it.

The other variable of the research design that is important is the proposition. It is clearly indicated that the rentier state theory is the foundation of the research. Based on the rentier state four methods, the researcher will assess the central government policies and activities that indicate the rentier state practices, and analyse the local/regional newspapers articles related to the rentier practices. The early research argument is that - the central government was practicing rentier state methods, especially through patronage, repression and large-scale distributive policy to buy off peace in the society; and the local newspapers' reactions towards it varied - some were pro-government, some stayed neutral by reporting facts, and some criticised the local and central government.

The next component is Indonesia as the analysis unit. Indonesia was under Suharto's authoritarian regime during the oil boom period. Indonesia has been producing oil since the colonial period, under the Dutch government, and in 1962, Indonesia joined OPEC. There was two oil shocks in the 1970s: the first was in 197374, and the second was in 1978-79. The oil shocks had changed Indonesia by increasing its export revenue from oil. The rentier state theory will be used to assess and analyse the relations between oil revenue with rentier state practices by the Indonesian government under Suharto. The time scope for the research will be the period between 1974 to 1982 - right after Indonesia benefited from the first oil shock, and right after the oil boom period ended and oil price fell in 1982.

The research data comes from multiple sources. The primary data will be taken from eight local/regional newspapers from Java, Bali and Sumatra which reported on Suharto's rentier-based economy practices, both at national and regional levels during the oil boom period, 1974-1982. Additional data from national newspapers, both primary and secondary sources, will be used to support the analysis and give broader explanation on mass media in Indonesia. Sources such as government-based report/data, together with books, articles, and research reports will be added to complete the explanation on the wider framework, the rentier state theory and practices, authoritarian regimes, Indonesian politics under Suharto and mass media in Indonesia.

In summary, the research aims to expand the rentier state literature that is mostly state-centric and switch the focus on rent receiver instead, by assessing and analysing local newspaper articles. There is on-going research on rentier state practice in the Middle East, Africa or South America expanding the focus on relations with Islamic ideology and rentier practice by local governments. Most of the research is still limited to central governments as the main focus of rent distribution, key features of rentier state theory, and oil revenue as one of state's main sources of income. This research will focus on the rent receiver and give more perspective on rent distribution by the central government. 


\section{INDONESIA'S RENTIER STATE PRACTICES}

Suharto came to power in 1966 and stayed in power for 32 years through winning six consecutive elections. Indonesia was one of OPEC members, and during the oil boom period, it captured the windfall of oil revenue from the high crude oil price. The oil revenue increased its economic growth with an annual average of 7.7 percent during 1974-1981 period (Thee, 2011, p. 155). It helped in raising Indonesia's per capita income from US\$260 in 1970 to above US\$500 in 1980, and reducing poverty rate which affected around 60 percent of Indonesians (Vatikiotis, 1999, p. 35). The oil boom became one of the reasons for Indonesia to practice rentier economy. Among four methods of rentier economy, at least three methods had been practiced in and adopted by Indonesia during the oil boom period.

\section{Repression}

Repression is a state's use of coercive force against political groups, including imposing limitations to public space for opposition, or other policies intended to constrain opposition-oriented political life (Moritz, 2018, p. 58). In the first period of the Suharto regime, repression was the main tool of the regime to get rid of its political enemies - the communists, the pro-Sukarno, the Islamists, and prodemocracy groups. The practice continued during the oil boom period under the Komando Operasi Pemulihan Keamanan dan Ketertiban or Kopkamtib. Kopkamtib was a concept within Indonesia's Armed Forces under the command of martial law, with no legal restraints on practicing its mandate to fight against threats to the state (Pancasila, the 1945 Constitution) or economic development. Under the 1957 martial law, Kopkamtib dominated the regional military command and had power over the civilians. The government used Kopkamtib to protect and increase the order and state security to achieve national stability, which led to the successful Five-Year Development Plan and Long-Term Development goals (Tanter, 1991).

Kopkamtib could not be touched with the regular legal channels, making it have extraordinary powers in practice. Kopkamtib was free to define 'criminality' and 'subversion', arrest without warrant and detain without trial, torture and interrogate, and many more. During the first oil shock, Kopkamtib had repressed Indonesia's media and information. It worked together with the Ministry of Information on reviewing publisher's licenses. It also worked with the Department of Labor Power to impose repressive measures on Indonesian labourers (Tanter, 1991).

Kopkamtib also carried out repressive acts toward students, especially after the demonstrations and riots in 1974 and 1978. It made the regime cut its ties with students, as well as revokes the licenses of student newspapers. Kopkamtib, together with the Ministry of Education, had also re-evaluated education policies for universities. The Ministry of Education developed a new policy called "Normalisation of Campus Life" which aimed to depoliticise campuses and make students focus on academic matters instead of becoming activists (Hill, 2006, p. 39). In the late 1980s, the organisation was dismissed with claims that its jobs were perfectly executed. There was no clear reason for its removal, but several sources mentioned that the external reasons were the critiques from the IGGI and the Non-Alignment Movement members over Suharto's repressive practices (Tanter, 1991). 


\section{Patronage}

Patronage politics can be defined as a special case of dyadic (two-person) ties involving an instrumental friendship in which an individual of high socioeconomic position (patron) uses his own influence and resources to provide protection or benefits for a person of lower status (client) who reciprocates by offering general support and assistance to the patron (Scott in Varkkey, 2013, p. 385). Four types of patronages were identified - with the Chinese Indonesian business, military elites, Yayasan and Golkar supporters, and district or Indonesian populations in general.

\section{Chinese Indonesian business}

The relations between the regime and Chinese Indonesian business/cukong is based on Indonesia's army and Chinese Indonesian traders back in the 1940s and 1950s (Vatikiotis, 1999, p. 50). Cukong became Suharto's informal finances to help the regime deliver economic growth based on the state's development plans. The cukong, because of their weak political position, needed support from the regime to stay in business by getting special treatment from the government and being granted privileges. The regime granted the cukong promotional privileges such as tariff protection, access to monopoly licenses, ease in getting government contracts, and access to subsidised credits. This resulted in the cukong being able to expand their businesses, contribute to the growth of the economy and provide the regime informal finances when it was needed. Liem Sioe Liong and William Soeryadjaja were a few of the many examples of cukongs who worked together with Suharto (Rock, 2017).

\section{Military elites}

Next, Suharto also maintained his relations with military elites through the dwifungsi doctrine. Dwifungsi doctrine refers to the two roles that Indonesian military served under the regime: role as a security force, and as a sociopolitical organisation. Military elites became involved in national politics and businesses, where military generals obtained positions inside the government and became leaders of state enterprises. In the government sector, military leaders not only held important positions within the central government in Jakarta, but also held positions in every region as well as small districts across the country. Meanwhile, in the business sector, state-owned companies like Pertamina, Tri Usaha Bhakti, and Berdikari, were under military leaderships (Pepinsky, 2008).

\section{Yayasan and Golkar supporters}

The third case is Suharto-Indonesian relations. In the late 1970s, Suharto established Yayasan Dharmais and Supersemar for his private source of patronage. Yayasan is considered as a charitable foundation, which makes it independent of government audit and tax (Vatikiotis, 1999, p. 51). Suharto through the yayasan gave scholarships and social services funds for Indonesians with the main purpose of making the receivers owe him and support his regime. Suharto extended his patronage by opening up Golkar for civilians and his political oppositions (in this case NU). Golkar gave civilians positions on the party's board and offered business opportunities to Muslim or other national entrepreneurs. In the business sector, businessmen such as Aburizal 
Bakrie and Arifin Panigoro benefited from the patronage after they became Golkar supporters (Mietzner, 2018, p. 90).

\section{Indonesia's population}

The last patronage practice was Suharto's relations with Indonesia's population. Suharto, through the Presidential Aid or BANPRES, spent the state's budget to fund several projects, which impacted Indonesia's population in large scale, especially farmers and villagers (Rock, 2017, p. 143). It was part of the election tools, too, that made Golkar dominate in every election during the regime period. Districts were promised to get development projects as long as they supported Golkar in the election. This type of patronage has close relations with the third type of rentier practice - the large-scale distributive policy.

\section{Large-scale distributive policy}

Large-scale distributive policy is well known as a populist policy where it is usually related to the public sector, such as employment opportunities, allocating subsidies or providing free education and healthcare (Basedau \& Lay, 2009, p. 761). The first oil shock boosted oil revenue from oil companies tax revenue. This immediately led to the government loosening its tax efforts especially for non-oil sectors and other corporate taxes. However, the huge oil revenue ended up being used to rescue Pertamina, which had debts amounting to US\$10 billion - equivalent to 30 percent of Indonesia's GDP at that time (Seda, 2014, p. 109). The government however, had managed to also use the oil revenue for the development sector, and Indonesia is accounted as one of the successful countries that turned oil revenues to strengthen its agriculture and industry.

In the agricultural sector, the government invested large amounts of money to develop agriculture and increase rice production. In the early stage of the price boom, 1973-74, the government imported large amounts of rice and fertiliser (Thee, 2011, p. 160). Imported fertilisers were distributed to farmers under subsidised price. Investment in agriculture research was accompanied with investment in irrigation. Through the government agency Bulog - Indonesian Bureau of Logistics, the government regulated the price of rice in the market. The result from agricultural reform during the oil boom period was that Indonesia achieved self-sufficiency in rice production in the mid-1980s (Usui, 1997, p. 156-157).

Industrial sector became the next development target under the oil revenue windfall. The first stage was the transition from import-substituting industrialisation to export-promoting industrialisation. The next step was the establishment of stateowned companies, upstream companies, and basic industries. The government worked together with Chinese Indonesian businesses and received foreign investment/aid and succeeded in building the sector - from fertilisers, cement plants, paper, steel to the engineering industry (Thee, 2011, p. 163). The industry development was supported by the development of the infrastructure. Suharto's regime was famous for its transmigration policy and family planning, and the oil revenues also funded both programmes. The transmigration policy became important to support the expansion of 
plantation businesses across Indonesia, such as coffee, coconut, palm oil, cocoa and so forth.

Regional development was promoted by the government under the so-called Instruksi Presiden/Inpres (Presidential Instruction). Inpres was about giving grants to local governments at different levels: province, district, and sub-district. The purpose of giving the grants was to promote rural infrastructure development. The Inpres grant scheme required local government to prepare plans and budgets. Should they get the grant, at the end of fiscal year, they were to submit a report of activities financed by the grant. The Inpres programme aimed at improving the quality and effectiveness of local public administration through systematic grant reports (Thee, 2011, p. 162).

\section{MEDIA ANALYSIS: NEWSPAPER COVERAGE OF GOVERNMENT RENTIER STATE PRACTICES}

In the early period of his regime, Suharto ordered the cleaning up of Persatuan Wartawan Indonesia/PWI (Indonesian Journalist Association) from leftist members. Soon, the regime regulated the press through legislative control. Presses need to get two different permits, namely Surat Izin Terbit/SIT (publishing permit) and Surat Izin Cetak/SIC (printing permit), before publishing their newspapers. SIT was issued under the Department of Information, while SIC was under Kopkamtib (Hill, 2006, pp.34-35).

The regime used mass media to support the New Order, especially military newspapers such as Berita Yudha and Angkatan Bersenjata. The government also controlled all broadcast media, such as TV Republik Indonesia/TVRI and Radio Republik Indonesia/RRI, and denied broadcast permission to others (Kaliailatu, 2007, p. 63). The other newspapers survived by establishing alliances with the military or adapting to the condition by changing their publication. At the end of the first year, the government enacted Basic Press Law in correlation with Article 28 of the 1945 Constitution on the freedom of expressing thought orally and through writing. types:

David T. Hill (2006, p. 36) classified the press in the early 1970s into six

1. Radical press (Harian KAMI, Mahasiswa Indonesia, Nusantara, Pedoman, and Indonesia Raya)

2. Politically cautious press (Sinar Harapan and Kompas)

3. Organs/pro-government press (Berita Yudha, Suara Karya, and Angkatan Bersenjata)

4. Radical nationalist press (El Bahar, Merdeka, and Suluh Indonesia)

5. Muslims press (Abadi, Jihad, and Duta Masyarakat)

6. Popular-style press (Pos Kota)

In the 1970s, the regime applied multiple bans for mass media following the riots and demonstration in 1974 and 1978. In the early 1970s, press as 'pers perjuangan' were actively criticising government policies. Indonesia Raya was one of the newspapers that attacked the regime with criticisms. Other newspapers, like Sinar Harapan had leaked the details of the 1973/74 National Budget Proposal. The regime, together with Kopkamtib started to take out radical newspapers' printing and 
publishing permits (Hill, 2006, p. 38). The Ministry of Information explained that the decision to shut down several newspapers was due to its concern over the escalation of situation that was threatening national stability. Dhakidae (1991, pp. 315-16) explained in his dissertation that the ban was not supported by an official decree, thus rendering it to be an illegal act with no legal provision. As there were no legal procedures, it could be seen as a demonstration of the power of the regime over its society (Hill, 2006, p. 39). The tension between the regime and the press in the 1970s continued in the 1980s.

The campaign on Pancasila ideology was accompanied with another ban in January 1983 when Expo magazine was banned after its publication on "Indonesia's 100 Millionaires". The article was about wealthy Indonesians whereby some of them were part of the New Order patron-client relations. Another ban came to Jurnal Ekuin when it reported on the impending reduction of the floor price for export oil. Topik experienced suspension for publishing two articles tending to arouse class hatred among the poor (Weatherbee, 1985, p. 191). Besides banning newspapers, the government also imposed regulations that affected their survival by giving limited space permit for advertisement. The regime used Dewan Pers (Press Council) to issue a regulation that only gave 35 percent of total column spaces for advertisement (Hill, 1992, p. 4).

In 1982, the Department of Information replaced Surat Izin Terbit/SIT (publishing permit) with Surat Izin Usaha Penerbitan Pers/SIUPP (press publication enterprise permit) (Hill, 1992, p. 4). The new permit required the newspaper editorial staff to become a member of Persatuan Wartawan Indonesia/PWI (Indonesian journalist association) (Hill, 1992, p. 4). The PWI itself was controlled by government loyalists, and to obtain full PWI membership, several requirements were needed, such as having to submit certificate of good behavior, certificate of G30S non-involvement, working in same national press companies, passing PWI test and so forth (Hill, 2006, p. 69). Under Suharto, the government tried to use mass media as the agent of stability for his authoritarian rule (McCargo, 2003, p. 75).

The change in press regulation was accompanied with a huge project under the New Order, called Koran Masuk Desa/KMD. KMD was a programme under the Department of Information, which served the purpose of introducing newspapers into villages and small towns. In early 1980, the initial programme covered 34 newspapers, and continued to increase to 43 in 1981. Under the KMD program, the press received subsidies for publication with special KMD village editions. The subsidies brought life to regional and pro-government newspapers because the government to be distributed to villages for free regularly purchased their publications. The program was initiated to increase the reading habit of Indonesians, especially in villages where mass media was rarely available.

The regime also implemented new legislation that required press companies to sell 20 percent of their shares to their staff (Hill, 2006, p. 49). The purpose for this regulation was to make the staff feel more responsible over the newspaper's life so they would avoid from being more critical towards government policies which could lead to the newspaper being banned and make them lose their shares (Hill, 2006, p. 49). The whole government pressure towards the press brought a positive result for the regime. In the 1980s, several new regulations were implemented and brought a 
massive shift for the press industry - from engaging in debates over government policies and its implementation, to fighting for financial survival of the company.

There were several newspapers that managed to survive under the New Order. During the whole period of New Order, more than 25 cases of SIT/publishing permit cancellations without judicial process were recorded (Kakiailatu, 2007, p. 65). The newspapers that survived were mostly those that took adaptive behavior towards the government. Newspapers such as Kompas turned to be less critical to keep them away from government target of bans or regulations. Before 1980, Kompas was active in criticising the government through the writing of various articles, such as "Keseluruhan Program Transmigrasi Terhambat", "Iklim Perekonomian Sebabkan Tidak Banyak Orang Mampu Beli Buku", "Kelemahan Administrasi Merupakan Faktor Penghambat Pembangunan", "Apa Yang Dilakukan Ahli-ahli Asing Sebenarnya Dapat Dikerjakan Ahli-ahli Sendiri", and "Cegah Komisi Impor Jatuh Ketangan Perusahaan Asing". After 1980, Kompas tended to be adaptive and less critical towards the government as the regime continued to apply bans which led to the closure of several newspapers. In the 1980s, the newspapers also learned to express their criticisms in different ways by using more positive words (Hill, 2006, p. 47). In the late 1980s and 1990s, the regime continued to apply several bans and new regulations for mass media, including the 'Pancasila Press' idea - "press which is free, but responsible".

The rentier state practices under Suharto's regime consisted of three practices: repression, patronage and large-scale distributive policy. It is quite hard to find articles on state repression, both in national and local newspapers. Among the national and local newspapers referred to in this research (12 newspapers), it was found that Pikiran Rakyat was the only one that reported on repression by Kopkamtib. In its 17 January 1974 edition, the front page of the newspaper was full with reports on the Malari incident, and an article with the title "Kopkamtib Terpaksa Bertindak" which reported on how Kopkamtib had arrested demonstrators and used hard power on civilians. The newspaper coverage on patronage however, can be found in national newspapers as seen from the previous explanation. The patronage types were SuhartoChinese Indonesian business relations, and Suharto-military relations. Indonesia Raya, Expo, and Jurnal Ekuin had articles on Chinese Indonesian businessmen who had close relations with the president, while Berita Yudha, a pro-government newspaper, had an article that showed Suharto-military relations through the appointment of military elites for civil positions.

The third rentier practice was large-scale distributive policy. At the national level, it was found that newspapers like Kompas, Abadi, and Berita Yudha reported on government policies with limited coverage. In one edition, Abadi for example, only had two articles, "45 Projek Inpres di Madura Dapat Diselesaikan" and "Dinas PU Bali Sedang Giat Selesaikan Dam Tukad". Kompas, a little bit better than Abadi, wrote several articles relating to the large-scale distributive practice negatively or with criticisms. Meanwhile, Berita Yudha, a pro-government newspaper, covered broader practices with positive language. "Kalsel Sediakan Tanah-tanah Luas Buat Transmigran", "Pengadaan dan Penyaluran Bahan Pokok di Kaltim Lancar" and "Kebijaksanaan Ekspor Baru Bawa Berbagai Efek Ganda Positif" were some examples taken from Berita Yudha. Local newspapers, compared to national ones, covered more of this third rentier practice. 
There were eight local newspapers from Java, Sumatra and Bali. Karya Darma, Masa Kini, and Surabaya Post were local newspapers from Java, while Waspada, Atjeh Post and Lampung Pos were local newspapers from Sumatra, and Bali Post and Nusa Tenggara were based in Bali. All eight newspapers covered the large-scale distributive policies, including education, health, infrastructure or development projects, the civil servant salary budget, Pertamina's scandal, and so forth. The news coverage was mostly focused on regional or local areas where the policy came into effect. In Sumatra, Atjeh Post covered the Aceh area with some articles on education and health programmes, and infrastructure projects. Articles such as "30\% Dari Nilai Proyek Untuk Oknum Pejabat? GUBERNUR MINTA DATA KONKRIT UNTUK DITINDAK”, "Kesan-kesan dari Daerah Pedalaman: Profil Aceh Barat Dewasa Ini", "Master Plan Banda Aceh Baru Dalam Tahap Penjajakan" and "Tiga Desa Jadi Korban Rencana Muluk" were focused on infrastructure and development programmes in Aceh. Articles such as "Di Pedalaman Aceh Banyak Ditemui Penderita Gondok: Belum Pernah Diadakan Yodisasi Garam", "Sedikit tentang KB" and "Tanggung Jawab Kita Sekarang untuk Mensukseskan Keluarga Berencana" were reporting on government health programmes, while articles on education programmes could also be found, such as "Dibutuhkan 38 Unit Gedung SD Lagi di Kabupaten Pidie" and "SMP Swasta Desa Terpencil itu Masih Kurang Peralatan" which talked about areas which needed more infrastructure support from the government. Atjeh Post also covered reports on government spending on its civil servants or government programmes through articles "Penataran P4 Gunakan Rp.1 Milyar" and "Honor di DPRD Aceh Naik".

Other newspapers that covered areas in Sumatra were Waspada and Lampung Pos. Waspada was based in Medan, and just as Atjeh Post, it also covered infrastructure or development, agriculture and education programmes. Articles on infrastructure projects were easy to find, such as "Jembatan \& Beberapa Jalan Rusak Berat", "Irwilda Terpaksa Ikut Awasi Mutu Jalan" and "3 Desa di Kec. Bilah Hilir Dapat Bantuan Stimulan dari Gubsu". Other articles that covered education programme included, "Kerusakan Gedung Inpres di Medang Deras" and "Pembangunan Gedung SD 'Semau Gue!", and "Kursus Pemberantasan Hama Tikus" covered part of the government agriculture programme. Moving to Lampung, located in South Sumatra, Lampung Pos articles focused more on the central government programmes, namely on transmigration, agriculture, education and health. Reports on transmigration programmes, could be found in articles such as "DESA TAMPANG DAN TRANSMIGRASI" and "Menggala Minta Transmigran". As for agriculture programmes, there were articles which were related to Bimas, namely "Disbun Propinsi Lampung Salurkan Bibit", "10 DESA IKUTI BIMAS", "PROYEK BIMAS TANAMAN KERAS PERTAMA DI INDONESIA", "BIMAS LADA" and "3 Pabrik Gula Akan Dibangun di Lampung" which were written in the Lampung Pos.

In Java, there were three newspapers, Masa Kini from Yogyakarta, Karya Darma and Surabaya Post from Surabaya. Masa Kini 's coverage was slightly broader with articles focusing on the military regime, politics, and social programmes. Masa Kini had articles on Indonesia's military, such as "KASAD Jenderal Poniman: 51 Kompi ABRI Masuk Desa" and "Dari Kemanunggalan Hingga ABRI Masuk Desa", and articles, which discussed politics, such as "DPA Menilai Keadaan Politik Stabil" and "Dr. Ruslan Abdulgani: Islam Di Indonesia Berfungsi Sebagai 
Pemersatu". On social programmes, articles such as "30 Pimpinan Organisasi Wanita Dilatih Manajemen”, "Wagub DIY: Masalah Utama DIY Kelebihan Tenaga Kerja", "Bupati Banjarnegara Berjanji Beri Pekerjaan Rekanan Muda", and "Pembangunan Tapurnas Borobudur Masih Menunggu SK Menkeu" were found in the 1980 edition. Another article related to the economy could also be found, such as "Dalam kaitannya dengan Keppres 14 A: Kadin DIY Ingin Jembatani Kepentingan Pengusaha", "Emping Pandeglang Diekspor" and "Prof. Dr. Mubiyarto: Kenaikan Harga Gula Sudah Diduga Sebelumnya".

In East Java, two newspapers based in Surabaya dated early 1980s provided news coverage around Surabaya area, including nearby cities, such as Malang, Madura, Mojokerto, Kediri and so forth. Karya Darma discussed several government programmes, such as infrastructure projects and education programmes. On infrastructure projects, articles which were written included "Listrik bawah laut ke Pulau Madura berfungsi tahun 1985", "Proyek-proyek Inpres tahun 1980-1981 untuk daerah Kabupaten Malang", "Komisi C DPRD Kodya Surabaya meninjau pembangunan Pasar Inpres", "Paket Inpres untuk Kodya Mojokerto", and "HATI MASYARAKAT AKAN TENTRAM - Kalau 8 Jalur Pemerataan Terlaksana Dengan Baik". Other articles on education programmes were "Sebanyak 31 Guru SD Dilantik", "Bangkalan Tambah 315 Guru SD Inpres", "Guru Inpres, guru agama dan penjaga SD untuk Kabupaten Kediri" and "Pogalan dan Watulimo punya Gedung SMPN".

Articles by Surabaya Post showed different coverage by focusing more on politics within a broader area. Articles related to politics could be seen from several titles, such as "Tingkatkan kehidupan demokrasi", "Hukum dan keadilan bukan menjadi hak rakyat, tetapi harus dibeli", "Mulai thun ini calon pegawai negeri akan ditatar", and "Ada gelagat, Demokrasi Pancasila mau dirusak". Surabaya Post also covered speeches by bureaucrats discussing politics - "Mendagri: Pemilu gelanggang pendidikan politik rakyat", "20 Feb, Hari Buruh Indonesia - Menteri Nakertrans: Jadi pimpinan buruh tidak mudah", "Wapres Adam Malik: Ikatan Wanita Pengusaha Indonesia perlu terus memantapkan fungsinya" and "Gubernur serahkan lagi sertifikat tanah: "Masyarakat jangan mudah termakan isu politik". Similar to other local newspapers, it also reported on development projects carried out by the government, "Pelabuhan Tg. Perak lakukan peningkatan menyeluruh", "Masjid KMS Bertingkat dua", "Dibangun Tempat Penampungan Ikan Segar", "Panti PKK dibangun", "Malang Selatan mendapat prioritas penangan" and "Akan dibangun lagi 16 kantor pos baru".

Bali Post and Nusa Tenggara, based in Bali, are the last two newspapers for the analysis. Bali Post was similar to Surabaya Post, and had news covering some national issues. It reported on the Pertamina scandal, shown as, "Persoalan Keuangan Pertamina: Tak Lepas dengan Kelanjutan Pembangunan", "Masalah Pertamina Harus Dijadikan Pelajaran", "Pidato Akhir Tahun Presiden Soeharto: Th. 1975 Bangsa Indonesia akan lebih berhasil - Tahun 1974 penuh tantangan tapi dapat kita atasi", and "Pidato Tutup Tahun 1975 Presiden Soeharto: Th. 1976 Kita Masuki dengan Tetap Prihatin \& Waspada". Similar to the rest, Bali Post also reported on the government large-scale distributive program, for examples "Pertama kalinya Jembrana Lampaui Target KB", "Dept. kesehatan "Merangkul” 34.000 dari 70.000 
Dukun Bayi", "Bantuan untuk Organisasi-organisasi Kesenian", "Penyerahan Rumah Dinas Murah" and "Di Denpasar akan dibangun "Service Centre" Pertenunan".

The Nusa Tenggara newspaper from 1980 was a village special edition, therefore the articles were mostly focused on village development programmes. Articles on government assistance to villages dominated its pages, such as "Usahausaha Pelembagaan NKKBS lewat Program KB/K Terpadu: Pendekatan Kemasyarakatan yang Komunikatif Perlu Ditingkatkan", "Penyerahan KIK untuk Petani Tambak di Kab. Dompo", "Bupati Bima telah serahkan dana bantuan desa untuk 10 kecamatan di Bima", "Desa Talibeng akan memiliki balai pasar serba guna", "10.000 Butir Bibit Kelapa Disumbangkan untuk Banjar KedampalKarangasem", "Desa Julah Peroleh Proyek Land Reform dari Dirjen Agraria" and so forth. Articles on government efforts to give training for villagers could also easily be found - "Kursus Pembinaan Kesejahteraan Keluarga", "Penyuluhan Pertanian", "Kursus Belajar untuk Anggota PKK Pedesaan Tangkup", "Dipupuk Kelompok Minat Pemuda Desa Pacung", "Nelayan-nelayan di Desa Lebih Terima Penjelasan Masalah Kredit", "3 Kecamatan di Klungkung Mengikuti Latihan Pembimbing Sosial", and "Pemuda-pemuda Desa Seba Dilatih".

All eight local newspapers covered the regime's rentier state practices, especially the large-scale distributive policy. However, they showed different attitudes towards the government. Their articles on government policies or national issues could be categorised into those, which chose to support the government programmes; act neutral; or criticise it. Waspada and Atjeh Post were the most vocal towards the government, especially the regional or local government. Waspada had several critical articles, such as "Pengembangan Transmigrasi non Petani", "Kejari Meulaboh Kasa-kusuk Cari Oknum Wartawan", "Kesemrawutan Bangunanbangunan di Kota Medan Tidak Kalah dari Semrawutnya Lalu Lintas", and "Penyelewengan Klas Teri di Pemda Medan Diperiksa". Waspada also criticised the central government through its articles, "Rencana Biaya Pemilu 82 Rp.120 Milyar Antara Logis \& Tak Logis", "Bantuan ADB untuk Kotamadya Medan", "Dicari Tenaga-tenaga Ahli Indonesia", and "Manpower Planning Perlu Segera Dibuat". The newspaper's caricatures were also quite vocal towards local and central governments, "Ngeri, ah! Kalau Program Peningkatan Mutu Pendidikan di Sumut Sampai Gagal! Hehe...", "Bagaimana Pemberantasan Korupsi di Pemda Medan? Masih ada Rp. 7,9 Juta yang "Sangkut" di Dinas Bangunan", and their comments in Bisik Berisik column. The newspaper had a reader's column, and in the 31 December 1980 edition, a letter from a reader criticised the local government through "Keluh Kesah Masyarakat Desa Kedai Durian".

Atjeh Post was another newspaper, which focused on criticising the local government, however, under the title it shows their support towards the central government (the regime). It was written as "Atjeh Post: Suara Independent Pengawal dan Pengamal Pancasila". The critics were mostly focused on resident dissatisfaction over bad infrastructure and bad government performance. On infrastructure problems, there were articles such as "Di Meulaboh Konsumen Telepon Menggerutu", "Tanjakan di Geureute Mengundang Maut Kalau Tidak Diurus", "Produksi Perikanan Laut di Aceh Makin Menurun", "Jembatan Negara Karieng Jurusan SigliB.Aceh Rusak Berat", "Kondisi Jalan Sabang Memprihatinkan" and "Dari Celahcelah kita: Setiap Pagi? Mahasiswa Berdesakan". Critics towards the government 
could be seen in articles "Dari Arena Rakerda BKKBN Aceh" and "Tanah Perkebunan Masih Digarap Secara Liar: Akibat Di Legalisir Oknum Pejabat". Similar to Waspada, Atjeh Post also had a reader's column and APA TAMPOK, as well as Rampagoi columns that tended to criticise the government.

Unlike Waspada and Atjeh Post, Karya Darma, Surabaya Post, Bali Post and Nusa Tenggara were newspapers that supported the government, specifically to the regime's ideology and programmes. Karya Darma published several articles that showed its support towards the regime, like "Ny Soenandar: Menghayati \& mengamalkan Pancasila merupakan amanat konstitusional", "Pangkowilhan II: Tempatkan manfaat Resimen Mahasiswa pada konteks yang luas", "Transmigran Jatim berangkat ke Sulsera", "Pengeboran minyak bumi terus dilanjutkan", and "Pengkopkamtib: "Usaha subversi masih akan berlangsung selama 2-3 Dasawarsa mendatang". Its caricature column also showed the support through "Jadi lurah bukan asal jadi... harus bisa menghayati arti pembangunan nasional". The other Surabayabased newspaper, Surabaya Post, showed its support through articles such as "Bunuhmembunuh di Jember telah dapat dikuasai", "Terbentang medan kekaryaan yang makin luas", "Presiden Soeharto: Hendaknya semua lebih mampu kendalikan diri" and "Gubernur serahkan lagi sertifikat tanah: "Masyarakat jangan mudah termakan isu politik". Besides, it also supported central government programmes in the article "Koran Masuk Desa telah memperluas penerangan di pedesaan".

Nusa Tenggara village edition was one of the strong pro-government newspapers. Nusa Tenggara attitude, which showed its support to the regime, was understandable as it was part of the Koran Masuk Desa (KMD) programme and received money from the government to keep its operation. Nusa Tenggara put "Menunjang Pembangunan untuk Mempertinggi Ketahanan Nasional" under its title and in mid-1980, it added information published under the KMD program, * diterbitkan dalam rangka proyek koran masuk desa*. It was easy to spot articles that showed support of the regime's programmes, such as telling a successful story of transmigration "Transmigran Asal Bali Penghasil Kedele Terbesar di Sulut", and support the KMD program - "Gubernur pada HUT PWI ke-34: Pers Agar Ikut Mencerdaskan Kehidupan Masyarakat Pedesaan *PWI Himbau Pemda Bali dan Kabupaten Bantu Pengembangan Koran Masuk Desa" and "Ringkasan dari Redaksi: Koran Masuk Desa dan Desa Masuk Koran". Articles which supported government's health and social programme could also be found, such as "Made Puguh Berikan Motivasi KB Lewat Karya Lukisan" and "Keluarga Bahagia sebagai Jalur Penghayatan Pengamalan Pancasila". Nusa Tenggara also published articles that encouraged villagers to support national development programmes, for example, "Masyarakat Semaon Berbenah Diri Meningkatkan Kesejahteraan", "Pembangunan Desa tidak Terpisahkan dari Pembangunan Nasional", "Desa Ungasan di Hijaukan dengan Gamal \& Lamtoro *Hayati dan taati ajara tri Ita Karana" and "Kaum Wanita agar lebih berperan dalam pembangunan".

Bali Post was similar to Nusa Tenggara in that it adopted an attitude of supporting the regime. Several articles showed its support, such as - "Menyambut Tahun Baru di Denpasar: Banyak Dikaitkan dengan "Bisnis", "Raker Gubernur seIndonesia: Peningkatan Layani Masyarakat dan PEMILU", "Memberikan Kesejahteraan yang dapat dirasakan rakyat" and "Universitas punya fungsi dan tanggung-jawab Menempa Mahasiswa: Menteri Syarif Thayeb". In the extreme case, 
the newspaper in its 3 January 1975 edition published an article titled "Dubes Sutopo Yuwono: Tidak Ada Militerisme" which rejected the claim that Indonesia was under militarism, and stated that Suharto's regime, military and the society are one. Bali Post also supported the government's KMD program through articles on its staff training, "Mengikuti Loka Karya Pers IX di Ujung Pandang: "Koran Masuk Desa" Untuk Apa? (III)" and "Mengikuti Loka karya Pers IX di Ujung Pandang: Ber "DwiFungsi" di Hutan-hutan Belukar". Bali Post can be said to tend to support the regime, however, it also threw soft critics to government programmes, especially on the government's decision to raise civil servant salaries through its articles, "RAPBN Bali Tahun ini Terbesar" and "Tajuk Rencana: Yang Ditunggu Prestasinya!".

Lampung Pos and Masa Kini were two newspapers that lay outside the two sides of being critical and pro-government. Lampung Pos mostly published articles that tended to be neutral by adopting titles and news coverage writing as normal reports. Articles such as "HARI KESEHATAN NASIONAL KE X DIPERINGATI", "PELAKSANAAN FISIK PROYEK-PROYEK", "P.U. SEKSI LAMPURA BIROKRASI" and "KODYA PERLU MASTER PLAN" were only explaining the facts of government programmes without using criticisms/sarcasm or positive support towards the programmes. Masa Kini was somewhat different from Lampung Pos in that it put heavy Islamic ideology in its paper. Neutral articles, pro-government articles and critical articles could be found in this newspaper. It had a reader's column, which on 3 September 1980, published a letter, which voiced out a reader's disappointment with the title "Apakah Yang Berwenang Tak Punya Planning". Neutral articles, such as "Telepon Masuk Desa Selesai Tahun ke 3", could be found, as well as progovernment articles, such as "Sekretariat Bersama Tripartite: Perlu Dikeluarkan Peraturan Mengenai Hak Mogok".

\section{CONCLUSION}

All eight local newspapers adopted different attitudes or approaches towards Suharto's rentier economy practices. Generally speaking, all of them were reporting the regime's rentier practices through three different writing styles - neutral, critical and pro/supportive. Neutral articles were found among all eight newspapers, yet some newspapers showed more pro/supportive articles or critical articles. Waspada and Atjeh Post were two among eight that tended to be critical towards the local and central governments. Two newspapers from Surabaya, Karya Darma and Surabaya Post, and two newspapers from Bali, Nusa Tenggara and Bali Post, were those, which published more pro-government articles. The last two sources, Lampung Pos and Masa Kini published neutral articles. Besides writing critical articles, local newspapers were mostly found using their special column on reader's letters, news comment or sarcasm in their comments to explicit and implicitly express their critics towards the local and central governments. The critical column was a small part dedicated within a whole page of the newspaper, located between pages 1 to 4 . Karya Darma had Pojok, Masa Kini had Pendapat Pembaca, and Waspada had Bisik Berisik and Pembaca Menulis. Atjeh Post had Apa Tampok and Rampagoi, while Bali Post had Catatan Bang Pojok.

Local newspapers effectively used their small columns to send critical messages to readers about government policies, however the approaches by the local newspapers and national newspapers were different. National newspapers tended to 
have vocal opinions towards government rentier practices, while local newspapers tended to support the government with limited critical articles towards local and central governments. Local newspapers somehow shared the important role of creating understanding of the regime's policies in different regions across Indonesia. By examining local newspapers, the large-scale distributive practices could be analysed in more detail, and the readers' or local newspapers' reactions/attitudes towards it showed the rentier receivers' perspectives. In all the local newspaper articles, it showed the rentier practice at sub-governmental level and Indonesia's residents' attitude towards it. Some supported the programmes and obtained results from it at every level, and in all sectors - education, health, social, agriculture and so forth. Some demanded more development/infrastructure projects, and some criticised the performances of the local and central governments.

\section{ACKNOWLEDGEMENTS}

This research was generously supported by Haraguchi Memorial Asia Research Fund. Thank you to Shinzo Hayase (Waseda University) who supervised the research, and to the anonymous reviewers for their insightful comments.

\section{REFERENCES}

-. (1972, March 29). Abadi, pp.1-4.

-. (1979, June Week-V). Atjeh Post, pp.1-4.

-. (1979, July Week-I). Atjeh Post, pp.1-4.

-. (1980, October Week-III). Atjeh Post, pp.1-4.

-. (1975, January 2). Bali Post, pp.1-4.

-. (1975, January 3). Bali Post, pp.1-4.

-. (1975, February 3). Bali Post, pp.1-4.

-. (1975, March 31). Bali Post, pp.1-4.

-. (1975, April 1). Bali Post, pp.1-4.

-. (1976, January 2). Bali Post, pp.1-4.

-. (1975, January 16). Berita Yudha, pp.1-4.

-. (1975, January 17). Berita Yudha, pp.1-4.

- (1982, January 30). Berita Yudha, pp.1-4.

-. (1980, June 3). Karya Darma, pp.1-4.

-. (1980, December 30). Karya Darma, pp.1-4.

-. (1979, August 20). Kompas, pp.1-4.

-. (1979, August 31). Kompas, pp.1-4.

-. (1979, December 31). Kompas, pp.1-4.

-. (1974, November 13). Lampung Post, pp.1-4.

- (1974, November 19). Lampung Post, pp.1-4.

- (1974, December 18). Lampung Post, pp.1-4.

-. (1975, January 2). Lampung Post, pp.1-4.

- (1980, September 3). Masa Kini, pp.1-4.

-. (1980, November 15). Masa Kini, pp.1-4.

-. (1980, March 2). Nusa Tenggara, pp.1-4.

-. (1980, June 1). Nusa Tenggara, pp.1-4.

-. (1980, June 8). Nusa Tenggara, pp.1-4.

-. (1980, December 28). Nusa Tenggara, pp.1-4. 
—. (1974, January 17). Pikiran Rakyat, pp.1-4.

-. (1981, January 2). Surabaya Post, pp.1-4.

-. (1981, January 31). Surabaya Post, pp.1-4.

-. (1981, February 20). Surabaya Post, pp.1-4.

-. (1981, February 21). Surabaya Post, pp.1-4.

-. (1980, December 16). Waspada, pp.1-4.

-. (1980, December 31). Waspada, pp.1-4.

Basedau, M. \& Lay, J. (2009), Resource curse or rentier peace? The ambiguous effects of oil wealth and oil dependence on violent conflict. Journal of Peace Research, 46, 6, 757-776. doi: 10.1177/0022343309340500

Dhakidae, D. (1991). The state, the rise of capital and the fall of political journalism: Political economy of Indonesian news industry. (PhD Thesis), Ithaca, NY: Cornell University. Retrieved from ProQuest Dissertations \& Theses Global. (303956978).

Hill, D. (2006). The press in new order Indonesia. Jakarta: PT. Equinox Publishing Indonesia.

Hill, H. (1992), Regional development in a boom and bust petroleum economy: Indonesia since 1970. Economic Development and Cultural Change, 40, 2, 351379.

Kakiailatu, T. (2007), Media in Indonesia: Forum for political change and critical assessment. Asia Pacific Viewpoint, 48, 1, 60-71. doi:10.1111/j.14678373.2007.00330.x

Lucas, V. \& Richter, T. (2016), State hydrocarbon rents, authoritarian survival and the onset of democracy: Evidence from a new dataset. Research and Politics, 3, 2, $1-9$.

McCargo, D. (2003). Media and politics in Pacific Asia. Retrieved from http://ebookcentral.proquest.com

Mietzner, M. (2018), Authoritarian elections, State capacity, and performance legitimacy: Phases of regime consolidation and decline in Suharto's Indonesia. International Political Science Review, 39, 1, 83-96.

Moritz, J. (2018), Reformers and the rentier state: Re-evaluating the co-optation mechanism in rentier state theory. Journal of Arabian Studies, 8, 1, 46-64.

Pepinsky, T. B. (2008), Capital mobility and coalitional politics: Authoritarian regimes and economic adjustment in Southeast Asia. World Politics, 60, 43874.

Price, K. H. (1998). The politics of Dutch disease: Institutions and the management of oil booms and busts in Venezuela and Indonesia. (PhD Dissertation), Massachusetts: Harvard University. Retrieved from ProQuest Dissertations \& Theses Global. (304435519).

Rock, M.T. (2017). Dictators, democrats, and development in Southeast Asia: Implications for the rest. New York: Oxford University Press.

Rosser, A. (2007), Escaping the resource curse: The case of Indonesia. Journal of Contemporary Asia, 37, 1, 38-58.

Seda, F. (2014). Petroleum paradox: Natural resources and development in Indonesia 1967-1997. Jakarta: Penerbit Universitas Indonesia.

Smith, B. (2006), The wrong kind of crisis: Why oil booms and busts rarely lead to authoritarian breakdown. Studies in Comparative International Development, $40,4,55-76$. 
Smith, B. (2007). Hard time in the lands of plenty: Oil politics in Iran and Indonesia. Ithaca, NY: Cornell University Press.

Tanter, R. (1990). Oil, IGGI and US hegemony: The global pre-conditions for Indonesia rentier militarization. In A. Budiman, (Ed.), State and civil society in Indonesia (pp. 51-98). Melbourne: Monash University.

Tanter, R. (1991). Intelligence agencies and third world militarization: A Case Study of Indonesia, 1966-1989. (PhD Thesis), Melbourne: Monash University. Retrieved from https://nautilus.org/network/associates/richardtanter/indonesian-intelligence/thesis/thesis-toc/

Thee, K. W. (2011), The impact of the two oil booms of the 1970s and the post-oil boom shock of the early 1980s on the Indonesian economy. The Indonesian Quarterly, 39, 2, 155-167.

Usui, N. (1997), Dutch disease and policy adjustments to the oil boom: a comparative study of Indonesia and Mexico. Resources Policy, 23, 4, 151-162.

Varkkey, H. (2013), Malaysian investors in the Indonesian oil palm plantation sector: home state facilitation and transboundary haze. Asia Pacific Business Review, $19,3,381-401$.

Varkkey, H. (2015). Natural resource extraction and political dependency: Malaysia as a rentier state. In M. L. Weiss (Ed.), Routledge handbook of contemporary Malaysia (pp.189-199). New York: Routledge.

Vatikiotis, M. (2013). Indonesian politics Under Suharto: The rise and fall of the new order (Third Edition). New York: Routledge.

Weatherbee, D. (1985), Indonesia in 1984: Pancasila, politics, and power. Asian Survey, 25, 2, 187-197. doi:10.2307/2644302 